\title{
A META ANAYSIS ON THE ASSOCIATION BETWEEN FAMILY BEHAVIOR OF SMOKING AND SMOKING BEHAVIOR IN ADOLESCENTS
}

\author{
Florida Betty Apriliyani'), Agus Kristiyanto²), Bhisma Murti1) \\ 1)Masters Program in Public Health, Universitas Sebelas Maret \\ ${ }^{2)}$ Graduate Program in Sport, Faculty of Educational and Teaching, \\ Universitas Sebelas Maret
}

\begin{abstract}
Background: Recently there has been increased interest in family-based interventions both to deter adolescent substance abuse in general and to prevent adolescent cigarette smoking specifically. The purpose of this study was to investigate the association between family behavior of smoking and smoking behavior in adolescents.

Subjects and Method: A meta-analysis and systematic review was conducted by collecting published articles from 2000 to 2020 in PubMed, Springer Link, and Google Scholar databases. This study used "parenting style" OR "family influence" AND "smoking" AND "behaviour" AND "adolescents" AND "cross sectional" keywords to obtain the articles. The inclusion criteria were full text, using English or Indonesia language, and using cross-sectional study. The selected articles were analyzed by Revman $5 \cdot 3$.

Results: 6 articles from Lithuania, Kelantan, China, Weh Island (Indonesia), and United States reported that smoking behavior of family member increased the likelihood of smoking behavior in adolescents $(\mathrm{aOR}=2.05 ; 95 \% \mathrm{CI}=1.69$ to $2.49, \mathrm{p}<0.001)$ with $\mathrm{I}^{2}=0 \%$. Conclusion: Smoking behavior of family member increases the likelihood of smoking behavior in adolescents.
\end{abstract}

Keywords: parenting style, family influence, smoking behavior, adolescents

\section{Correspondence:}

Florida Betty Apriliyani. Masters Program in Public Health, Universitas Sebelas Maret. Jl. Ir. Sutami 36A, Surakarta 57126, Central Java. Email: ridhaflorida@gmail.com. Mobile: 081329329417. 